\title{
FAKTOR-FAKTOR PENYEBAB AGRESI VERBAL SISWA
}

\author{
Oleh: \\ Haslinda $^{1)}$, Jahada ${ }^{2)}$, Dodi Priyatmo Silondae ${ }^{3)}$ \\ 1) 2) 3) Jurusan Bimbingan dan Konseling \\ Fakultas Keguruan dan Ilmu Pendidikan, Universitas Halu Oleo \\ Email: haslinda@gmail.com
}

\begin{abstract}
ABSTRAK
tujuan penelitian ini adalah untuk mengetahui faktor-faktor penyebab agresi verbal siswa di MTs. Negeri 4 Bombana. Penelitian ini adalah penelitian kualitatif yaitu penelitian yang bertujuan memahami fenomena tentang apa yang dialami oleh subjek penelitian yang dilakukan secara holistic. Informan dalam penelitian ini adalah 1 guru BK, 1wali kelas dan 2 orang siswa MTs. Negeri 4 Bombana. Hasil penelitian menunjukkan bahwa dari 250 siswa peneliti memeroleh 2 siswa yang mengalami agresif verbal. Faktor-faktor penyebab agresi verbal siswa di MTs. Negeri 4 Bombana yaitu faktor internal (faktor frustasi, faktor gangguan pengamatan, faktor gangguan berfikir, dan faktor gangguan perasaan/emosional) dan faktor eksternal (faktor lingkungan keluarga, faktor lingkungan sekolah, dan faktor lingkungan sosial).
\end{abstract}

Kata Kunci: Agresi Verbal Siswa.

THE FACTORS CAUSING THE STUDENTS VERBAL AGGRESSION

\begin{abstract}
The purpose of the research was to find out the factors causing the students verbal aggression of the public Madrasah Tzanawiah (MTs) 4 Bombana. The purpose of this qualitative research was to understand the phenomenon of what were experienced by the subjects of the research. The research was carried out holistically. The informants of the research were 1 guidance and counseling teacher, 1 homeroom teacher, and 2 students of public MTs 4 Bombana. The findings of the research reveal that off 250 students, the researchers finds that there are two students who has experienced by verbal aggressive. Factors causing the students verbal aggressions of public MTs 4 Bomana are two factors; internal factors and external factors. Internal factors include frustration, observing problem, thinking problem, and feeling and emotional problems. External factors include family environment, school environment, and social environment.
\end{abstract}

Keywords: Students Verbal Aggression 


\section{Pendahuluan}

Agresi verbal adalah tindakan yang mengarah kepada ujaran kebencian yang dilakukan melalui ucapan atau penuturan lisan. Secara teoritis, perilaku agresif verbal adalah salah satu fenomena yang menunjukkan perilaku tidak dapat mengontrol emosi atau bersikap agresif, seperti kasar terhadap orang lain, suka bertengkar mulut, memaki-maki, sering mengolok-olok dan bertemperamen tinggi (Siwinarti, Tajri \& widodo, 2012: 1).

Agresi verbal terjadi karena tidak mampu mengontrol emosi yang ada pada dirinya individu sehingga menyebabkan pertengkaran mulut, menghina, mengolok-olok antara individu satu dengan yang lainnya. Perilaku ini yang bertujuan menyakiti perasaan orang atau individu lain. Perilaku tersebut sangat memengaruhi perkembangan siswa dalam berinteraksi antara sesama. Kemampuan dalam berinteraksi atau komunikasi dapat dilihat dari cara bertutur kata antar individu satu dengan yang lainnya. Agresi verbal siswa dapat dilihat di lingkungan sekolah karena sekolah merupakan lingkungan pendidikan yang kedua untuk mengembangkan dirinya. Lingkungan ini sangat berpengaruh dengan perkembangan dalam mengaktualisasikan diri siswa dan merupakan tempat bersosialisasi. Dalam sosialisasi terdapat interaksi antara sesama siswa, dalam interaksi tersebut dibutuhkan komunikasi yang sopan dari perkataan (verbal) namun ada beberapa siswa yang tidak dapat mengontrol perkataannya sehingga dapat menyinggung perasaan teman, seperti "berbicara kotor", menghina teman dan sebagainya. Perilaku tersebut terjadi di Madrasah Tsanawiyah (MTs) Negeri 4 Bombana.

Berdasarkan penjelasan guru BK MTs Negeri 4 Bombana bahwa agresi verbal dialami oleh siswa adalah berperilaku tidak sesuai dengan norma yang berlaku di sekolah seperti berbahasa kasar, menghina, bertengkar, mengejek, marahmarah, dan berteriak. Perilaku siswa yang seperti ini merupakan perilaku yang buruk di sekolah. Hasil wawancara tersebut diperkuat dari catatan kasus di sekolah seperti berbahasa kotor, menghina, bertengkar, mengejek, marah-marah dan berteriak.

Agresi verbal merupakan perilaku yang dilakukan oleh individu dan menimbulkan dampak negatif pada individu yang lain. Perilaku ini merupakan kenakalan remaja yang harus dikendalikan oleh orang tua, guru, masyarakat dan diri sendiri. Agresi verbal adalah perilaku individu yang menunjukkan ketidak mampuan mengontrol emosi.

Masa perkembangan siswa merupakan masa yang mudah bergejolak dan keguncangan karena sifat emosionalnya masih labil. Masa remaja biasa dianggap sebagai periode "badai dan tekanan" suatu masa dimana ketegangan emosi meninggi sebagai akibat dari perubahan fisik dan kelenjar. Dalam masa transisi yang dialami remaja, cenderung membawa dampak psikologis di samping membawa dampak fisiologis, perilaku mereka cenderung berpikir pendek dan ingin cepat dalam memecahkan berbagai permasalahan kehidupan.

Hurlock (2006: 208) mengemukakan bahwa masa remaja dikatakan sebagai masa yang tidak realitis. Masa ini merupakan salah satu perilaku menyimpang yang sering muncul di kalangan remaja, yaitu kurang mengontrol emosi dan mudah untuk mengungkapkan dengan kemarahannya melalui kata-kata kasar. Perilaku tersebut dikenal sebagai perilaku agresi verbal yakni perilaku yang muncul dalam bentuk kata-kata kasar seperti menghina, teriak, bertengkar, kritikan, dan katakata kasar lainnya. Perilaku ini tidak dapat dibiarkan karena dapat memengaruhi perkembangan komunikasi siswa dalam bersosialisasi dan dapat menimbulkan perilaku agresi nonverbal.

Masalah agresi verbal tidak dapat dibiarkan begitu saja, karena akan menimbulkan kekerasan fisik pada individu yang lain dan memengaruhi perkembangan komunikasi siswa dalam bersosialisasi. Bentuk perilaku siswa lainya yang merupakan agresi verbal adalah menggosip, menghina mengejek, bertengkar, marah-marah, berteriak, memboikot (tidak mau bicara), memfitnah dan memaki.

Upaya pemberian bantuan terhadap masalah tersebut memerlukan keterangan yang jelas tentang keadaan diri siswa yang sebenarnya, salah satunya adalah dengan mengetahui faktor-faktor penyebab siswa agresi verbal. Dengan cara itu maka proses pemberian bantuan kepada siswa dapat benarbenar menyelesaikan akar permasalahannya, sehingga siswa dapat bebas dari masalah agresi verbal. Hal ini dapat mendorong penulis untuk melakukan penelitian guna mengungkapkan berbagai penyebab agresi verbal dalam sebuah penelitian dengan judul "Faktor-faktor Penyebab Agresi Verbal Siswa di MTs. Negeri 4 Bombana". Penelitian ini bertujuan untuk mengetahui faktor- 
faktor penyebab agresi verbal siswa di Madrasah Tsanawiyah (MTs) Negeri 4 Bombana.

Berkowitz (dalam Kurniawati dan Prattiwi, 2014:508) menyatakan bahwa perilaku agresif verbal adalah bentuk perilaku atau aksi agresif yang diungkapkan untuk menyakiti orang lain, perilaku agresif verbal dapat berbentuk umpatan, celaan, makian, ejekan, fitnahan dan ancaman melalui kata-kata.

Myers (dalam Kulsum dan Jauhar, 2014: 245) menyebut agresif adalah perilaku fisik atau lisan yang disengaja dengan maksud untuk menyakiti atau merugikan orang lain. Perilaku agresif adalah perilaku yang menyerang, melukai, meremehkan, merugikan, mengejek dan memfitnah. Perilaku tersebut merupakan salah satu fenomena perilaku yang menunjukkan ketidakmampuan mengontrol diri (emosi) sehingga berbuat kasar pada yang orang lain.

Sears dkk (dalam Kulsum dan Jauhar, 2014: 253), menyatakan bahwa perilaku agresif adalah perulaku yang memunyai maksud melukai dan lebih pasti terdapat perbuatan yang bermaksud melukai dan berdampak sungguh-sunguh melukai.

Berdasarkan definisi tersebut peneliti menyimpulkan bahwa perilaku yang muncul dalam bentuk kata-kata kasar seperti menghina, bertengkar, marah-marah, mengejek dan berteriak merupakan agresi verbal.

Buss (dalam Kurniawati dan Pratiwi, 2014: 508) membagi jenis-jenis perilaku agresi verbal sebagai berikut:

1. Agresi vebal aktif langsung, yaitu tindakan agresi verbal yang dilakukan oleh individu atau kelompok lain, seperti menghina, memaki, marah dan mengumpat.

2. Agresi verbal positif langsung, yaitu tindakan agresi verbal yang dilakukan oleh individu atau kelompok dengan cara berhadapan dengan individu atau kelompok lain namun tidak terjadi kontak verbal secara langsung seperti menolak bicara atau bungkam.

3. Agresi verbal aktif tidak langsung, yaitu tindakan agresi verbal yang dilakukan oleh individu atau kelompok lain dengan cara tidak berhadapan secara langsung dengan individu atau kelompok lain yang menjadi targetnya, seperti menyebar fitnah dan mengadu domba.

4. Agresi verbal pasif tidak langsung, yaitu tindakan agresi verbal yang dilakukan oleh individu atau kelompok dengan cara tidak berhadapan dengan individu atau kelompok lain yang menjadi targetnya dan tidak terjadi kontak verbal secara langsung, seperti tidak memberi dukungan dan tidak menggunakan hak suara.

Selanjutnya, Baron (dalam Shaikh, dkk. 2014: 2) menyatakan jenis agresif verbal terdiri dari 4 jenis, yakni:

1. Verbal-active-direct yaitu menghina atau merendahkan orang lain.

2. Verbal-active-indirect yaitu menyebarkan berbahaya rumor atau gosip tentang orang lain.

3. Verbal-pasif-direct yaitu menolak untuk berbicara dengan orang lain, untuk menjawab pertanyaannya.

4. Verbal-pasif-indirect yaitu gagal memebuat komentar verbal secara spesifik bila diperlukan.

\section{Metode Penelitian}

Penelitian ini telah dilaksanakan di MTs. Negeri 4 Bombana, yang bertempat tinggal di kelurahan Dongkala. Peneilitin ini dilakukan dalam kurun waktu selama satu (1) bulan. Jenis penelitian ini adalah penelitian studi kasus kualitatif yang bertujuan untuk menggambarkan atau mengetahui secara mendalam mengenai faktor-faktor penyebab agresi verbal siswa di MTs. Negeri 4 Bombana.

Peneliti memeroleh informasi dengan melakukan metode wawancara, yang dimana peneliti melakukan wawancara dengan 1 guru Bimbingan dan Konseling, 1 wali di MTs. Negeri 4 Bombana dan melanjutkan wawancara kepada 2 siswa di kelas VIII.2.

Langkah-langkah analisis data dalam penelitian ini merujuk pada pandangan Miles dan Huberman (dalam Sujarweni, 2014: 34) yakni sebagai berikut:

1. Reduksi data. Reduksi data merupakan proses pemilihan, pemusatan perhatian pada penyederhanaan, pengabstrakan, transformasi data kasar yang muncul dari catatan-catatan tertulis yang diperoleh dilapangan. Langkahlangkah yang dilakukan adalah menajamkan analisis, menggolongkan ke dalam tiap permasalahan melalui uraian singkat, mengarahkan, menghilangkan yang tidak perlu dan mengorganisasikan data sehingga dapat ditarik dan diverifikasi. Tujuan penelitian dapat digunakan oleh peneliti adalah sebagai acuan dalam mereduksi data sehingga data yang tidak sesuai dengan tujuan dapat direduksi.

2. Penyajian data. Pada proses ini peneliti mengategorisasikan data yang menurut pokok permasalahan dan dibuat dalam bentuk matriks sehingga memermudah untuk melihat pola-pola hubungan satu data dengan data 
lainnya. Penyajian data dapat dilakukan dalam bentuk uraian naratif, bagan, hubungan antar kategori serta diagram alur. Penyajian data dalam bentuk tersebut memermudah peneliti dalam memahami apa yang terjadi. Pada langkah ini, peneliti berusaha menyusun data yang relevan sehingga informasi yang didapat disimpulkan dan memiliki makna tertentu untuk menjawab masalah penelitian.

3. Penarikan kesimpulan. Tahap ini merupakan tahap penarikan kesimpulan dari kegiatan reduksi dan penyajian data. Data yang sudah direduksi dan disajikan secara sistematis akan disimpulkan sementara. Penarikan kesimpulan atau verifikasi adalah usaha untuk memahami makna, keteraturan, pola-pola, penjelasan, alur sebab akibat. Kesimpulan dalam penelitian kualitatif merupakan temuan baru dimana dapat memberikan gambaran suatu objek yang sebelumnya masih samar-samar sehingga setelah diteliti menjadi jelas (tidak samarsamar).

Kesimpulan yang dihasilkan dalam penelitian ini diarahkan untuk menjawab seluruh permasalahan penelitian dan memberikan gambaran tentang faktor-faktor penyebab agresi verbal siswa di MTs. Negeri 4 Bombana.

\section{Hasil Penelitian dan Pembahasan Hasil Penelitian}

1. Faktor internal

a. Faktor frustasi

Faktor frustasi merupakan faktor yang meliputi perasaan kecewa yang dapat menyebabkan terjadinya agresi verbal. Perasaan tersebut secara otomatis akan menjadi pendorong atau penyebab seseorang berbicara kasar, menghina, bertengkar, mengejek, marahmarah (agresi verbal) terhadap orang lain. Faktor frustasi ini dapat menyebabkan siswa bertindak agresi karena disebabkan adanya perasaan kecewa atau perasaan marah terhadap individu lain sehingga melampiaskan dengan cara berbicara kasar, bertengkar dan menghina. Berdasarkan informasi yang diperoleh melalui wawancara pada siswa yang bersangkutan dikemukakan bahwa dengan berbicara kasar, bertengkar, mengejek dan marah-marah dapat menghilangkan perasaan kecewa atau tersakiti terhadap teman-temannnya (merasa senang) dan akan melawan ketika diganggu, sehingga dengan adanya perasaan senang maka siswa tersebut cenderung berbicara kasar, menghina, bertengkar dan marah-marah.

Dari hasil wawancara tersebut maka faktor frustasi merupakan faktor penyebab agresi verbal pada siswa karena perasaan siswa dengan tindakan melawan dapat membuat ia senang.

b. Faktor gangguan pengamatan atau tanggapan

Faktor gangguan pengamatan merupakan faktor penyebab yang merujuk pada penglihatan dan tanggapan yang tidak baik sehingga menjadi pendorong untuk berbicara kasar, menghina, bertengkar, dan marah-marah, hal ini biasanya membuat individu mendapatkan teguran atau hukuman.

Berdasarkan hasil wawancara pada siswa yang berbicara kasar, menghina, bertengkar dan marah-marah dikemukakan bahwa siswa tersebut tidak senang diganggu, dikritik dan ia beranggapan bahwa ketika ia melakukan hal tersebut tidak akan diganggu oleh temannya sehingga siswa tersebut sering berbahasa kasar, menghina, mengejek dan marah-marah.

Penjelasan tersebut sesuai dengan keterangan guru wali kelas yang diperoleh melalui wawancara, guru wali kelas mengemukakan bahwa apa yang dikemukakan siswa tersebut benar karena siswa yang bersangkutan tidak suka digangu. Keterangan ini dapat didukung dengan hasil wawancara kepada guru bimbingan dan konseling yang mengemukakan bahwa apa yang dikemukakan siswa benar karena dari pertanyaan guru Bimbingan dan Konseling yang diberikan kepada siswa seputar dengan perilaku yang dialami, siswa mengemukakan bahwa agar tidak diganggu oleh temannya maka ia melawan dengan cara berbahasa kasar, menghina, mengejek dan marah-marah.

Berdasarkan penjelasan tersebut dapat disimpulkan bahwa faktor gangguan pengamatan atau tanggapan dapat disebut sebagai penyebab agresi verbal karena adanya tanggapan siswa yang baik tentang sifat melawan sehingga mendorong siswa berbicara kasar, menghina, mengejek dan marah-marah.

c. Faktor gangguan perfikir atau intelegensi

Faktor gangguan berfikir merupakan pemikiran dan kepercayaan yang tidak baik dan dapat menyebabkan berbahasa kasar, menghina, bertengkar, mengejek dan marah-marah. Pemikiran tersebut dapat mendorong seseorang 
berbahasa kasar pada orang lain. Berdasarkan informasi yang diperoleh dari siswa melalui wawancara dikemukakan bahwa siswa yang berbicara kasar dan marah-marah dapat menolong dirinya karena ia dapat melawan ketika diganggu dan tidak merasa ada masalah, sehingga ia cenderung berbahasa kasar, menghina, bertengkar, mengejek dan marahmarah.

Hasil wawancara menunjukkan gangguan berfikir atau intelegensi merupakan faktor penyebab agresi verbal pada siswa karena muncul pemikiran siswa yang tidak baik sehingga berbahasa kasar, menghina, bertengkar, mengejek dan marah-marah dapat menolong dirinya ketika diganggu.

d. Faktor perasaan atau emosi

Faktor perasaan atau emosi merupakan perasaan yang dapat meyebabkan siswa berbahasa kasar dan marah-marah, jika perasaan ini diikutkan maka tidak akan ada komunikasi yang baik dalam berinteraksi antara individu yang satu dengan yang lain. Berdasarkan informasi yang diperoleh melalui wawancara kepada siswa yaitu ia mengemukakan bahwa dengan adanya perasaan emosi terhadap teman baiknya ia langsung keluarkan dengan cara marah-marah dan berbicara kasar, sehingga setelah ia marahmarah perasaannya akan senang. Dari hasil wawancara tersebut maka faktor gangguan perasaan atau emosi merupakan penyebab agresi verbal siswa karena emosi siswa jika diikutkan akan membuat ia senang.

Dari beberapa faktor tersebut dapat disimpulkan sebagai penyebab agresi verbal karena adanya perasaan marah pada siswa dan dapat dilihat dari perilaku siswa yang mudah tersinggung dan tidak sependapat dengan teman di sekolah.

2. Faktor eksternal

a. Faktor lingkungan keluarga

Lingkungan keluarga merupakan faktor lingkungan yang sangat dekat dan berpengaruh kepada setiap orang. Faktor tersebut mudah untuk memengaruhi perilaku siswa karena lingkungan keluarga merupakan lingkungan pertama mendapatkan didikan yang biasa disebut dengan didikan orang tua. Berdasarkan informasi yang diperoleh melalui wawancara kepada siswa yang agresi verbal yaitu ia mengemukakan bahwa sering bertengkar, marah-marah dengan adiknya di rumah dan sering juga di marahi oleh ibunya.

Dari keterangan tersebut dapat disimpulkan bahwa faktor lingkungan keluarga dapat memengaruhi siswa berperilaku agresi verbal karena tidak memiliki hubungan komunikasi yang baik dalam rumah, khususnya komunikasi kepada adik.

b. Faktor lingkungan sekolah

Faktor lingkungan sekolah merupakan faktor yang sangat berpengaruh kepada siswa saat berada di lingkungan sekolah, sehingga siswa memiliki karakter yang berbeda khususnya dalam berinteraksi dengan teman dan guru. Berdasarkan informasi yang diperoleh dari wawancara kepada siswa diketahui bahwa ia berbahasa kasar, mengejek, berteriak dan marah-marah karena sering diganggu oleh teman sehingga ia mudah tersinggung. Berdasarkan uraian tersebut dapat disimpulkan bahwa faktor lingkungan sekolah merupakan penyebab agresi verbal karena di sekolah terdapat teman yang sering mengganggu.

c. Faktor lingkungan sosial (masyarakat)

Faktor lingkungan sosial merupakan faktor lingkungan yang dapat memengaruhi seseorang dimana ia beradaptasi. Lingkungan ini didapat di luar sekolah, seperti dalam pergaulan seharihari. Lingkungan tersebut sangat berbengaruh terhadap seseorang apabila berada di lingkungan yang kurang baik, sehingga jika tetap beradaptasi di lingkungan tersebut maka akan menimbulkan hal yang tidak baik, khusunya cara berinteraksi dengan baik. Berdasarkan informasi yang diperoleh dari wawancara kepada siswa, ia mengemukakan bahwa banyak teman di luar sekolah yang komunikasinya kurang baik, dalam hal ini suka berbahasa kasar, marah-marah, menghina, mengejek dan berteriak. Dari uraian tersebut dapat disimpulkan bahwa lingkungan sosial (masyarakat) penyebab agresi verbal siswa karena terbiasa berteman dengan orang yang suka berbahasa kasar, marah-marah, menghina, mengejek dan berteriak.

\section{Pembahasan}

Agresif verbal adalah salah satu fenomena yang menunjukkan peLaku tidak dapat mengontrol emosi atau bersikap agresif, seperti kasar terhadap orang lain, suka bertengkar mulut, memaki-maki, sering mengolok-olok dan bertemperamen tinggi (Siwinarti, Tarji \& Widodo, 2012: 1). Agresi 
verbal dipengaruhi oleh beberapa faktor, yaitu faktor internal (faktor dari dalam diri) yang terdiri dari faktor frustasi, faktor gangguan pengamatan atau tanggapan, faktor berfikir atau intelegensi dan faktor gangguan perasaan atau emosi, sedangkan faktor eksternal (faktor dari luar diri) yang terdiri dari faktor lingkungan keluarga, lingkungan sekolah dan lingkungan sosial (masyarakat). Beberapa faktor penyebab agresi verbal pada siswa MTs. Negeri 4 Bombana yaitu faktor internal yang terdiri dari faktor frustasi, faktor gangguan pengamatan atau tanggapan, faktor gangguan berfikir atau intelegensi dan faktor gangguan perasaan atau emosi dan faktor eksternal yang terdiri dari faktor lingkungan keluarga, faktor lingkungan sekolah dan faktor lingkungan sosial (masyarakat).

Faktor penyebab agresi verbal siswa MTs. Negeri 4 Bombana yang pertama adalah faktor frustasi. Faktor frustasi meliputi perasaan kecewa yang dapat menyebabkan terjadinya perilaku agresi verbal. Perasaan tersebut secara otomatis akan menjadi pendorong atau penyebab seseorang berbicara kasar, menghina, bertengkar, mengejek, marah-marah (agresi verbal) terhadap orang lain. Siswa yang agresi verbal merasa senang karena ia dapat melawan dengan cara berbicara kasar, bertengkar, mengejek dan marah-marah terhadap teman untuk menghilangkan perasaan kecewa, sehingga dengan perasaan inilah yang membuat siswa untuk terus berbahasa kasar, menghina, mengejek dan marah-marah. Dengan adanya perasaan seperti ini pada diri siswa maka pihak sekolah khususnya wali kelas dan guru Bimbingan dan konseling perlu memberikan perhatian dan himbauan bahwa berbahasa kasar, menghina, mengejek dan marah-marah dapat menyebabkan dampak negatif pada orang lain dan pada diri sendiri dan jika diikutkan secara terus menerus maka ia tidak akan bisa berkomunikasi dengan baik dalam bersosialisai di lingkungan sekitarnya.

Faktor kedua yaitu faktor gangguan pengamatan atau tanggapan, faktor gangguan pengamatan merujuk pada penglihatan dan tanggapan yang tidak baik sehingga menjadi pendorong untuk berbicara kasar, menghina, bertengkar dan marah-marah, hal ini biasanya membuat individu mendapatkan teguran atau hukuman. Siswa berperilaku tersebut karena ia merasa tidak senang diganggu dan dikritik sehingga ia berbicara kasar, menghina, mengejek dan marah-marah. Dengan hal seperti ini, maka guru bimbingan dan konseling perlu memberikan perhatian bahwa jika memertahankan diri tidak senang dengan kritikan maka akan sulit untuk berkembang dan maju.

Faktor ketiga yaitu faktor gangguan berfikir atau intelegensi, faktor berfikir meliputi pemikiran dan kepercayaan yang tidak baik dan dapat menyebabkan berbahasa kasar, menghina, bertengkar, mengejek dan marah-marah. Berdasarkan informasi yang diperoleh dari wawancara kepada siswa yang bersangkutan yaitu siswa berbicara kasar, menghina, bertengkar dan marah-marah karena ia merasa pikiran yang tenang dan puas ketika membalas teman yang mengganggu, maka dengan hal tersebut, pihak sekolah khususnya guru bimbingan dan konseling dan wali kelas perlu memberikan pemahaman dan himbauan bahwa dengan tindakan yang ia lakukan akan menimbulkan dampak negatif bagi orang lain maupun bagi diri sendiri.

Faktor keempat yaitu faktor gangguan perasaan, yaitu adanya perasaan yang tidak baik dan menyebabkan munculnya pertengkaran, amarah, ejekan dan hinaan. Berdasarkan hasil wawancara siswa, ia berbicara kasar, bertengkar, marah-marah, mengejek, menghina karena ia diboikot oleh teman sehingga perasaannya makin emosi. Selain dari faktor internal, ada faktor eksternal yaitu faktor lingkungan keluarga, faktor lingkungan sekolah, dan faktor lingkungan sosial (masyarakat). Faktor eksternal sangat berpengaruh terhadap perilaku siswa dalam beradaptasi di setiap lingkungan ia berada, khususnya dalam dalam berintaraksi.

Perilaku siswa disebut agresi verbal karena dipengaruhi oleh dua faktor, yaitu faktor internal yang terdiri dari faktor frustasi, faktor gangguan tanggapan, faktor gangguan berfikir, dan faktor gangguan perasaan dan faktor eksternal yang terdiri dari faktor lingkungan keluarga, faktor lingkungan sekolah dan faktor lingkungan sosial masyarakat. Hal ini dilihat dari cara komunikasinya dengan bahasa kasar, marahmarah, menghina, mengejek individu lain, khususnya teman di sekolah. Perilaku siswa muncul karena adanya perasaan kecewa atau marah yang disebabkan karena mudah tersinggung pada teman sehingga melampiaskan dengan cara tersebut dan setelah melampiaskan amarahnya siswa yang agresi merasa senang dan tenang. Perilaku siswa jika dibiarkan dapat menimbulkan dampak negatif bagi individu lain maupun bagi diri sendiri. 

yaitu:

Adapun dampak dari perilaku agresi verbal

1. Orang lain akan takut dan menghindar.

2. Orang lain akan membenci.

3. Orang lain mungkin akan membalas.

4. Tidak mampu berkomunikasi dengan baik dalam bersosialisasi.

5. Dapat merusak citra diri.

\section{Kesimpulan dan Saran \\ Kesimpulan}

Berdasarkan hasil penelitian dan pembahasan mengenai faktor-faktor penyebab agresi verbal siswa di MTs. Negeri 4 Bombana, dapat ditarik kesimpulan bahwa faktor-faktor penyebab agresi verbal adalah sebagai berikut:

1. Faktor internal

Faktor internal terdiri atas faktor frustasi, faktor gangguan tanggapan, gangguan berfikir dan gangguan perasaan. Faktor frustasi muncul karena adanya perasaan marah, faktor gangguan tanggapan dapat menyebabkan siswa agresi verbal siswa karena tidak menerima kritikan/ saran kemudian berfikiran untuk melawan. Kemudian gangguan perasaan muncul karena adanya perasaan marah pada diri yang selalu mendorong siswa berbicara kasar.

2. Faktor eksternal

Faktor eksternal merupakan faktor dari luar diri siswa yang terdiri dari faktor lingkungan keluarga, sekolah dan faktor lingkungan sosial masyarakat. Dari ketiga lingkungan tersebut merupakan penyebab siswa agresi verbal karena adanya hubungan yang tidak baik dalam lingkungannya.

\section{Saran}

1. Bagi kepala sekolah, harus berupaya untuk meningkatkan lingkungan sekolah yang kondusif, misalnya mengadakan kegiatan OSIS (rekreasi) karena salah satu penyebab agresi verbal adalah lingkungan.

2. Bagi wali kelas, dapat lebih melakukan upaya pencegahan terhadap agresi verbal dan dapat memberikan perhatian pada siswa mengenai cara berkomunikasi dengan baik dalam berinteraksi.

3. Bagi guru bimbingan dan konseling, dengan mengetahui faktor-faktor penyebab agresi verbal, guru Bimbingan dan konseling dapat lebih meneliti masalah yang dialami siswa agar dapat diberikan layanan yang tepat dan bersifat kuratif.

\section{Daftar Pustaka}

Bekiari. (2014). Verbal Aggressiveness And Leadership Style Of Sports Instructors And Their Relationship With Athletes' Intrisic Motivation. Universitas Thessaly, Jurnal Pendidikan Kreatif Vol. 5, No. 2, Hal. 114121.

Chaq. (2015). Religiusitas, Kontrol Diri dan Agresivitas Verbal Remaja. Skripsi. Universitas Surabaya.

Damayanti dan Aeni. (2016). Efektivitas Konseling Behavioral Dengan Teknik Modeling Untuk Mengatasi Perilaku Agresif Pada Peserta Didik Di SMP Negeri 07 Bandar Lampung. IAIN Raden Intan Lampung, Jurnal Bimbingan dan Konseling 03 (1).Hal. 1-10.

Daryanto dan Farid. (2015). Bimbingan Konseling Panduan Guru Bk Dan Umum. Yogyakarta: Gava Media.

Hamilton. (2012). Verbal Aggression: Understanding the Psychological Antecedents and Social Consequences. Universitas connecticut, storrs, CT, USA, Jurnal psikologi bahasa dan sosial 31 (1).Hal. 5-12.

Hurlock, E.B. (2006). Psikologi Perkembangan: Suatu Rentang Pendekatan Sepanjang Rentang Kehidupan (Edisi Ke 5). Jakarta: Erlangga.

Jahja. (2011). Psikologi Perkembangan. Jakarta: Kharisma Putra Utama.

Khiyaroh. (2017). Sukses Bersikap Tegas Dengan Siapa Saja, Kapan Saja Dan Dimana Saja. Yogyakarta: PT. Anak Hebat Indonesia.

Kulsum dan Jauhar. (2014). Pengantar Psikologi Sosial. Jakarta: Prestasi Pustakaraya.

Kurniawati dan Prattiwi. (2014). Implementation On Group Counseling Cognitive Behavior To Reduce Agresive Verbal Behavior Of Students In Class VII-SMPN I Ngunut Tulungagung. Universitas Negeri Surabaya. Tesis Bimbingan Dan Konseling. 
Nurtjahyo dan Matulessy. (2013). Hubungan Kematangan Emosi Dan Konformitas Terhadap Agresivitas Verbal. Universitas Surabaya. Jurnal Psikologi Indonesia Vol. 2, No. 3, Hal. 223-231.

Prayitno. (2004). Dasar-Dasar Bimbingan Dan Konseling. Jakarta: PT. Rineka Cipta

Restu dan Yusri. (2013). Studi Tentang Perilaku Agresif Siswa Di Sekolah. Universitas Negeri Padang. Jurnal Ilmiah Konseling Vol. 2, No. 1, Hal. 243-249.

Shaikh, dkk. (2014). Physical And Verbal Aggressive Behaviour Pattern Among School Children In Urban Area Of North Kartanaka: A Cross Sectional Study. Jurnal JKIMSU Vol.3, No. 2, Hal 1-8.

Siwinarti, dkk. (2012). Model Bimbingan Kelompok Dengan Teknik Fun Game Untuk Mengurangi Perilaku Agresif Verbal. Universitas Semarang. Tesis Bimbingan Konseling.

Sujarweni. (2014). Metodologi Penelitian. Yogyakarta: PT. Pustaka Baru Pres.

Susantyo. (2011). Memahami Perilaku Agresif: Sebuah Tinjauan Konseptual. Informasi Vol. 16, No. 3, Hal 189-202.

Trisnawati. (2014). Faktor-Faktor Yang Mempengruhi Perilaku Agresif Remaja Di SMK Negeri 2 Pekanbaru. Universitas Riau, JOM Psik Vol.1, No. 2, Hal. 2-3. 